\title{
Social Media and Its Role in Encouraging Individual Willingness to Mobilize Against Sexual Violence in Academia
}

\author{
Intan Primadini \\ Faculty of Communication Science, Universitas Multimedia Nusantara, Indonesia \\ \{intan.primadini@umn.ac.id\}
}

\begin{abstract}
The number of sexual abuse cases experienced by women in the education sector and victim blaming culture that still happen in Indonesia have motivated a lot of organizations focused in equality for women to begin the campaign movement. The objective of the campaign was to raise awareness on abuse cases experienced by women, the culture of victim blaming experienced by the majority of victims, and invitation to participate in moving against violence against women. Campaign messages are no longer only delivered through mainstream media, but also through social media. Most campaigns even focused on using social media in the dissemination of their messages. Instagram, as one of the most popular social media platforms today, is widely used to disseminate information about violence against women in academia. This study aims to find out the role of Instagram in encouraging individual willingness to mobilize against sexual violence in academia. This study is a quantitative research and data is obtained through survey using questionnaire. Based on the result of this study, it is known that image content was found to have the highest influence on willingness, while hashtags content had the least. Furthermore, there was a difference between male and female willingness to mobilize against sexual violence.
\end{abstract}

Keywords: Academia; Instagram; Social Media; Women; Violence against Women

\section{Introduction}

The case of Agni (not her real name), a student from the Gajah Mada University in Yogyakarta who was raped by her friend while conducting a Community Service (KKN) on Seram Island, Maluku, was proof that academia is not immune from acts of violence against women. Until now in Indonesia there is no comprehensive data on sexual crime on campus. However, based on e-mail complaint that was established by Rifka Annisa, a crisis center and non-profit institution that focused on eliminating violence against women based in Yogyakarta, in just one month there were eleven e-mails reporting the incidence of sexual abuse on campus; seven of them were conducted by lecturers on students [1]. These acts of harassment can occur in various forms, ranging from verbal abuse, catcalling, lewd behavior, 
and so on. The actors generally manipulate their power as lecturers. Campus is also slow, if not failed, in reforming itself to create a healthy academic environment [2].

The vast cases of abuse experienced by women in the education sector and victim blaming culture in Indonesia have motivated many organizations concerning women's equality begin the campaign movement on violence against women issue. Campaign messages are no longer only delivered through mainstream media, but also through social media. Most campaigns even focused more on using social media in the dissemination of their messages. As stated by Liou (2013) in her Working Paper entitled "Using Social Media for the Prevention of Violence against Women" that across the world, the tools of social media have assisted social movements. Social media has the ability to intensify the power of society to make changes, as a platform for discussion, contemplation, also affecting and mobilizing people [3].

Chittal (2015) stated that in addition to raising awareness, feminist activism has also created visible results through social media [4]. In 2013, a campaign organized by Women, Action, and the Media (WAM) had pressed Facebook to make some adjustments about their policies in allowing pictures that portray violence about women. In response, Facebook stated that they would be revising their community guidelines to prohibit hate speech related to gender. On the same note, The Prevention and Education Subcommittee of the Oregon Attorney General's Sexual Assault Task Force published a paper titled "A Best Practice: Using Social Media for Sexual Violence Prevention." On that paper, it was stated that social media could help to make some changes about sexual violence and sexual assault by disseminating notions, mindset, and awareness to the target audience [5].

Even though some people are still in doubt regarding the effectiveness of social media's power to affect changes in real world, over the years we have witnessed how far movementbuilding - online communities create a space for all voice, enabling those who have been overlooked or misrepresented for too long have been influenced by social media. Furthermore, social media also allowed organization to use digital channels to directly connect with broad and diverse audiences, give meaningful, two-way discussions, and mobilize people to act, all without dependent to mainstream media and other conventional communication networks. In this globalization era, social media has become a critical element of an effective communication strategy for every grassroots movement and nonprofit organization [6].

Instagram is one of the most famous platforms of social media. The main function of Instagram is simple yet eloquent: to share pictures. Gong (2014) stated that Instagram can be described as a platform for social networking focusing on photos and videos sharing via mobile phone [7]. Caption or description and hashtag (\#) could be added to the shared pictures/photos. The aim of the campaign carried out by all feminist accounts on Instagram is not only to increase awareness about the violence experienced by women, but also to encourage the community to move together to fight all forms of violence. That statement is in line with what was stated by WHO that the interventions of media seek to improve awareness, adjust, and alter behavior. It also can modify the norms and values of the society (e.g., the belief that femininity is related to weakness or masculinity is the synonym of aggressive) through communication and dialogue. Based on research, it is known that what makes media interventions successful is the ability to understand their audience's behavior and engaging the participants to initiate the intervention [8].

This research specifically uses the Instagram account "@lawanpatriarki" which until this research was made has 31,800 followers. This study aims to find out the role of Instagram in encouraging individual willingness to mobilize against sexual violence in academia. The difference in gender might affect the level of willingness to be involved in sexual violence against women campaigns, therefore the other objective off this study is to find out whether 
there is a difference between men and women in their willingness to mobilize against sexual violence. This research specifically discusses the content on social media that has the highest influence on individual willingness to mobilize against violence on women.

\section{Method}

A cross-sectional survey was conducted to measure the link of different contents on @ lawanpatriarki Instagram account with the individual willingness to mobilize against violence on women. Neuman (2014) defined research through a survey as quantitative research, where the researcher asks plenty of people the same questions systematically and then records the answers [9]. Many cases can be found in a large group of population. The Researcher then picks a sample out of it and generalize the result to the entire population (Neuman, 2014). The population of this study was the followers of "@lawanpatriarki" account on Instagram, amounted to 31,800 followers when this research was conducted. The sample size was 100 participants, which was calculated by using Yamane formula, and having the acceptable sampling error of 0.1 .

We sent direct messages on the @lawanpatriarki followers to invite them to participate in our survey. Of 250 direct messages sent, we received 100 responses and fulfilled our sampling size. The participants filled out our online questionnaire through the link in our direct message. We developed a 30-item questionnaire from the literature review. The questionnaire assessed the user's perception of the coherence and completeness of the different content [10], i.e. image, video, caption, hashtag [11] and Instastory [12], featured by @lawanpatriarki Instagram account. It also evaluated the users' willingness to mobilize against violence on women [13]. We used four-point Likert scale to calculate the summation of the user's acceptance of contents and willingness to mobilize against violence, which has been campaigned by the @lawanpatriarki. The questionnaire was piloted prior to the study and demonstrated a good validity and reliability (Cronbach's alpha $=0.788-0.887$ ).

Data were analyzed using univariate analysis to describe the participants' characteristics and user's reception on the Instagram contents (image, video, Instastory, caption, and hashtag) and their willingness to mobilize against violence. We then analyzed both variables (content and willingness) using correlation analysis. Correlation analysis is a method used to test the relationship between the variables used in a research [14]. The purpose of the correlation analysis is to measure the strength of linear correlation between variables [15]. Another test applied in his study is One Way Anova analysis aimed to compare means between dependent variables in all groups [16]. This research wanted to see whether there is a difference in Willingness to Mobilize against Violence between men and women.

\section{Result and Discussion}

Most respondents were female (77\%), aged 17-25 years (90\%), and had finished high school $(75 \%)$. The mean value of willingness to participate against sexual assault in women was 58.4158 and 58.1304 in men (table 1). This means that female respondents were more inclined than male respondents in participating on action against sexual violence, even though their mean values was not much different. The result of this study was in line with the study done by Armstrong \& Mahone (2017) which explained that women were significantly more likely to be engaged in collective movement against sexual violence than men. Similar result 
was stated by Kelly and Breinlinger (1996) that said one of the significant factors in involvement of collective action was perceived injustice. Hence, it was no surprise that, generally, women might be more than likely than men to be involved in collective action against sexual harassment and offline specifically as a form of group identity and solidarity [17].

Table 1. The Difference between Female and Male in Willingness to Mobilize against Violence

\begin{tabular}{ccc} 
& N & Mean \\
\hline Female & 77 & 58.4156 \\
Male & 23 & 58.1304 \\
Total & 100 & 58.3500 \\
\hline
\end{tabular}

This survey found that the overall perception on the Instagram contents was good. This can be seen from the mean values of all the variables which are above 3 (table 2). Respondents agreed that the images, videos, and Instastory contents are 'relevant' (mean $=3.22-3.41$ ), yet they rated the lowest when asked if the contents were 'unique'. On the willingness variable, the highest rating was given by the respondents on the statement of "Stating disagreement when heard someone said "they deserved to get raped" compared to the statement of "Asking stakeholders to reinforce the anti-violence against women act."

Table 2. Perception on the @lawanpatriarki's Instagram Contents and Willingness to Mobilize against Violence

\begin{tabular}{|c|c|c|c|c|c|c|}
\hline Variables & Highest Indicators & Mean & Mode & Lowest Indicators & Mean & Mode \\
\hline Image (X1) & $\begin{array}{c}\text { Informative, } \\
\text { Attractive, Relevant }\end{array}$ & 3.41 & 3 & Unique & 3.28 & 3 \\
\hline Video (X2) & Relevant & 3.39 & 3 & Unique & 3.13 & 3 \\
\hline $\begin{array}{l}\text { InstaStory } \\
\text { (X3) }\end{array}$ & Relevant & 3.38 & 3 & Unique & 3.15 & 3 \\
\hline $\begin{array}{l}\text { Caption } \\
\text { (X4) }\end{array}$ & Informative & 3.32 & 3 & Attractive, Relevant & 3.26 & 3 \\
\hline $\begin{array}{l}\text { Hashtag } \\
\text { (X5) }\end{array}$ & Relevant & 3.22 & 3 & Unique & 3.13 & 3 \\
\hline $\begin{array}{l}\text { Willingness } \\
\text { (Y) }\end{array}$ & $\begin{array}{c}\text { Stating } \\
\text { disagreement when } \\
\text { heard someone said } \\
\text { "they deserved to } \\
\text { get raped" }\end{array}$ & 3.62 & 4 & $\begin{array}{l}\text { Asking stakeholders to } \\
\text { reinforce the anti- } \\
\text { violence against women } \\
\text { act }\end{array}$ & 2.78 & 3 \\
\hline
\end{tabular}

Another thing to note that all specific statement regarding violence against women in academia, gained positive approval from all respondents. For instance, the statement "Willing to object (reprimand the assailant)" showed mean value of 3.41; "Reporting the assailant" showed value of 3.45; and "Reporting the assailant that sexually harassed my friend" got 3.42 in mean value. In conclusion, participation from the respondents has not yet moved toward legal action, despite most of them has signed petition on Eliminating Sexual Violence Bill (RUU Penghapusan Kekerasan Seksual - PKS), based on value of 3.14.

Furthermore, correlation and regression analysis were performed to see the correlation and influence between the Instagram contents and the willingness. As presented in table 3, all contents were significantly related with the willingness to mobilize against violence (all $\mathrm{p}$ $<0.000$ ). The image content showed to have the highest correlation with the willingness, 
proven by the Beta values of 0.490 . While the lowest correlation was on hashtag content with Beta value of 0.392 .

Table 3. The Correlation Between the Instagram Contents and Willingness to Mobilize against

\begin{tabular}{cccc}
\multicolumn{4}{c}{ Violence } \\
\hline Variables (X) & Beta (B) & R-square & p value \\
\hline Image & 0.490 & 0.240 & 0.000 \\
Video & 0.404 & 0.163 & 0.000 \\
InstaStory & 0.476 & 0.227 & 0.000 \\
Caption & 0.483 & 0.234 & 0.000 \\
Hashtag & 0.392 & 0.154 & 0.000 \\
Instagram Content & 0.528 & 0.279 & 0.000 \\
\hline *Variable Y: Willingness & &
\end{tabular}

The table above showed that majority of the respondents agreed that image had the biggest influence toward their willingness to mobilize against violence. This condition was in agreement with Rose (2017) which stated that what makes Instagram difference than any other platforms is their focus on image-sharing. Image is convincing because it has the power to represent the real thing from photos and videos. Rather than telling, pictures show you something and are more emotionally powerful than reading tons of words [18].

A surprising result in this analysis showed the low influence of the video uploaded to respondents' willingness to mobilize against violence. This is in contrast with the same statement from Rose (2017) that image is powerful, videos even more. My assumption is, @ lawanpatriarki account did not often upload videos on their posts therefore their followers were not motivated to act based on video's influence. We recommend future research on this issue.

Another founding was that respondents considered hashtags had the lowest influence toward willingness to act against violence. According to Neil Patel in his article titled "8 Ways to Create an Instagram Campaign That Will Blow Up Your Brand" there were some things regarding hashtags that needed to be considered when making a campaign. One of them is to make hashtag memorable and to be very clear about what it represents [19]. Meanwhile, some of the hashtags used by @lawanpatriarki even though they were easy to remember, but not specifically mentioned the issue. For example, the hashtag \#MerdekaItu (\#FreedomIs) and \#GerakBersama (MoveTogether). Patel added that one of the biggest frustration with campaign is having your hashtags used for another cause. This means the hashtags they used could be used to define other issues which might be remotely relevant with the main objective of their hashtag. Another argument is @lawanpatriarki account might not usually use hashtag in their post, making their followers unaware of the hashtag used.

Overall, Instagram content was found to have a correlation with the willingness proven by the Beta value of 0.528 (table 3). This result supported what Passy \& Giugni (2001) said in their research that social media platforms could allow the participant to involve in social campaigns. The individual can sign up to participate in a campaign where the more people involved, the more effective it is to address the issue [20].

\section{Conclusion}

Based on the result of this study, it is known that @lawanpatriarki Instagram content that was mostly perceived to be of relevance with the campaign was the image content, meanwhile 
the content that was considered less influential was the hashtag. For all Instagram contents, respondents considered that Photos, Videos, Instastories, Captions, and Hashtags were informative and relevant to the issue on violence against women. However, respondents also assumed that all posts on @lawanpatriarki were not unique. On willingness variable, majority of the respondents agreed that they will state disagreement when someone said "they deserved to get raped." However, they also stated that they would not ask stakeholders to reinforce the anti-violence against women bill. Image content was found to have the highest influence on willingness, while hashtags content had the least. Furthermore, there was a difference between male and female willingness to mobilize against sexual violence.

\section{References}

[1] Utami, W. T. (2017). Darurat Kejahatan Seksual di Kampus. Retrieved from https://tirto.id/darurat-kejahatan-seksual-di-kampus-cx7z

[2] Adam, A. (2018). Cerita Pelecehan Seksual di Kampus: Dosen Mesum Jadi Rahasia Umum. Retrieved from https://tirto.id/cerita-pelecehan-seksual-di-kampus-dosenmesum-jadi-rahasia-umum-cNpg

[3] Liou, C. (2013). Using Social Media for the Prevention of Violence against Women Lessons Learned from Social Media Communication Campaigns to Prevent Violence against Women in India, China and Viet Nam. 1-50. Retrieved from http://www.partners4prevention.org/sites/default/files/resources/socialmedia_final.pdf

[4] Chittal, N. (2015.). How Social Media is Changing the Feminist Movement. Retrieved from http://www.msnbc.com/msnbc/how-social-media-changing-the-feministmovement

[5] The Prevention and Education Subcommittee of the Oregon Attorney General's Sexual Assault Task Force. (2014). A Best Practice: Using Social Media for Sexual Violence Prevention. SATF Oregon.

[6] Haas, R. (2017). Developing Social Media Campaigns for Domestic Violence Awareness Month. National Resource Center on Domestic Violence.

[7] Gong, X. (2014). Strategic Customer Engagement on Instagram. Master Thesis, 1-42.

[8] WHO. (2009). Promoting gender equality to prevent violence against women. World Health Organization, 1-18. Retrieved from http://www.who.int/violenceprevention/publications/en/index.html\%0Ahttp://apps.who .int/iris/handle/10665/44098

[9] Neuman, W. L. (2014). Social Research Methods: Qualitative and Quantitative Approaches. Harlow: Pearson Education Limited

[10] Solis, B. (2019). Engage: The Complete Guide for Brands and Business to Build, Cultivate, and Measure Success in the New Web. In Journal of Chemical Information and Modeling (Vol. 53). https://doi.org/10.1017/CBO9781107415324.004

[11] Miles, J. G. (2019). Instagram Power: Build Your Brand and Reach More Customers with the Power of Pictures. In Journal of Chemical Information and Modeling (Vol. 53). https://doi.org/10.1017/CBO9781107415324.004

[12] Rouse, M. (2018). Instagram Stories. Retrieved from https://whatis.techtarget.com/definition/Instagram-stories

[13] Armstrong, C. L., \& Mahone, J. (2017). "It's On Us." The Role of Social Media and Rape Culture in Individual Willingness to Mobilize Against Sexual Assault. Mass 
$\begin{array}{lll}\text { Communication } \quad \text { and } & \text { 9ociety, }\end{array}$ https://doi.org/10.1080/15205436.2016.1185127

[14] Ghozali, Imam. (2013). Aplikasi Analisis Multivariete Dengan Program IBM SPSS 23. Semarang: Badan Penerbit Universitas Diponegoro. p.93.

[15] Kriyantono, Rachmat. (2016). Teknik Praktis Riset Komunikasi. Jakarta: Kencana Prenada Media Group. p.172.

[16] Raharjo, S. (n.d.). Cara Melakukan Analisis Anova Satu Faktor dengan SPSS. Retrieved from https://www.spssindonesia.com/2017/10/analisis-anova-satu-faktorspss.html

[17] Kelly, C., \& Breinlinger, S. (1995). Identity and injustice: Exploring women's participation in collective action. Journal of Community \& Applied Social Psychology, 5(1), 41-57. https://doi.org/10.1002/casp.2450050104

[18] Rose, D. (2017). Trendy Social Activists Prove Instagram is a Platform for More Than Selfies. Retrieved from https://www.vice.com/en_us/article/padwxn/trendy-socialactivists-prove-instagram-is-a-platform-for-more-than-selfies

[19] Patel, N. (n.d.). 8 Ways to Create an Instagram Campaign That Will Blow Up Your Brand. Retrieved from https://neilpatel.com/blog/8-ways-create-instagram-campaignwill-blow-brand/

[20] Passy, F., \& Giugni, M. (2001). Social networks and individual perceptions: Explaining differential participation in social movements. Sociological Forum, 16(1), 123-153. https://doi.org/10.1023/A:1007613403970 